\title{
RELATIONSHIP QUALITY AND EXHIBITOR'S PERFORMANCE IN LEISURE TRADE SHOWS
}

\author{
Ainhoa Rodríguez, María Dolores Reina, Ramón Rufín
}

\section{Introduction}

A trade show can be considered as a business event that generates a concentration of supply and demand in a specific place and on a regular basis, where participants (both exhibitors and visitors) can exchange opinions, receive information, and negotiate. Specifically, in the case of leisure trade shows the main purpose is to stimulate the rising leisure market and meet the needs of an increasingly demanding society that calls for new forms of entertainment.

Within the area of marketing, trade shows are treated as marketing tools that the company can use to achieve its sales objectives. Its purposes can be grouped into two categories [34]: sales and communication.

Over the last decade, trade shows have positioned themselves in the business market as one of the most profitable methods for promotion and as an important element within the distribution process, as one of the marketing tools that are best adapted to typically small and midsize Spanish companies. They have also been considered the best way to enhance a company's profile and its new products and detect new trends emerging in the marketplace. All in all, trade shows are a key element in the sales process [8]. In the specific case of the Spanish economy, the trade show industry received over 13.5 million visitors in 2009 [1]. The trade shows that were held during that year occupied over 3.5 million square meters and the total number of direct exhibitors was 58,281 . The industry has experienced considerable growth over the past ten years, with the number of trade shows rising from 240 in 1995 to 474 in 2009, a 95\% increase.

Trade shows have received much attention within scientific research [16], [43]. However, there have been relatively few empirical studies guiding companies as to the strategies and tactics they ought to pursue at these events in order to improve the exhibitor's performance.
In addition, almost all of the existing research about trade shows has focused on events in which exhibitors aimed their products at other specialized businesses, leaving nonprofessional visitors practically out of the loop. Over the course of history, trade shows have shifted from an emphasis on sales and the general public to an increasingly specialized professional focus. However, the general public continues to show an interest in attending these events in order to gather information and have a chance to see and try out new products which, in some cases, are difficult to find outside a trade show context.

Even less is the interest found in the literature for those trade shows addressed to the general public and which have a specific goal in showing and/or selling leisure products and services. In fact, the few existing references can be traced to the field of travel and tourism, where it seems that consumer travel show attendance may in turn be closely linked with the individual leisure desires of the visitor. Actually two clusters are suggested: 1) shopper cluster whose major motivation is purchasing, and 2) "total visitors" whose motivation is to undertake an ongoing information search and attend seminars to maintain their awareness of new trends with the tourism industry [44].

Furthermore, many trade shows are aimed at becoming leisure and cultural events in themselves and where visitors can spend some time and be entertained. Given the increasingly hedonistic profile of today's consumers, if a trade show venue implements a strategy aimed at providing an attractive setting for nonprofessional visitor consumption, it is bound to be successful.

The above considerations have lead the present research. The field work was conducted in EXPO-OCIO, which, at the time, was the most visited trade show in Spain and 
the foremost leisure trade show in Europe. Its main purpose is to stimulate the rising leisure market and meet the needs of an increasingly demanding society that calls for new forms of entertainment. The exhibited products and services at the trade show pertains mostly to the following categories: sports, travel and tourism, playing games, arts, media, gastronomy, and motor vehicles.

\section{Conceptual Framework}

Achieving and maintaining customer loyalty has become one of the main strategic goals for companies, and has been accepted as a critical factor for success in all kinds of organizations [23], [25], that requires awareness of the processes in which relational exchanges influence loyalty [49].

Stable, lasting relationships with customers enable service companies to reduce the adverse consequences of negative encounters that are inevitable due to the intangible, individual nature of services. In addition, reparation is a positive alternative, involving compensation given to a customer to make up for a failure in the service provided [18].

An overview of the existing literature about the determinants of relationship performance reveals several conceptual models that could explain a significant part of relationship success, relationship benefits, and relationship quality. Although relationship quality is associated with the nature of the relationship (pure relationshipmarketing components), whereas relationship benefits are associated with receiving utilitarianoriented benefits (transactional-marketing components), both concepts regard satisfying individuals' needs as a critical element for successful relationships [23].

Although the quality of the relationships between organizations and between organizations and their customers have been analyzed independently, it is important to use one single model to integrate the effects of both types of relationship quality - between different organizations and between organizations and their customers - on the performance obtained from participating firms [27], [22], [17], [48].

Complaint management refers to the strategies used by businesses to correct and learn from the mistakes they make in providing their services, in order to rebuild their customers' trust in the company. Customers judge how their complaints are handled according to the results they perceive for the process, the processes employed, and the interpersonal contact they have throughout the entire complaint management process. Addressing whatever mistakes or failures have occurred in service delivery is crucial for preserving relationship vitality. Most customers are not satisfied with the ways in which organizations handle their complaints, and therefore perceived justice in service recovery is also relevant [46], [30]. In turn, satisfaction is considered the main measure of purchase behavior, merging pre-purchase beliefs about the product with the post-purchase cognitive structure, communication with the consumer, and re-purchase behavior.

Effective complaint management strategies have a critical impact on the number of retained customers, market share, and repurchase likelihood, reducing the negative word-of-mouth effect and increasing performance. Service failure can threaten a customer's loyalty to the company. A reconversion process can help to transform service failures into positive actions that generate increasingly positive customer attitudes towards the firm [33], [39].

\section{Posited Hypotheses and Analysis Model}

In this paper we analyze the quality of the relationship between the leisure trade show venue and the exhibitor as well as between the exhibitor and its final customers as a single construct in each one of these cases, examining the effect that the quality of the relationship between the leisure trade show venue and the exhibitor has on the quality of the relationship between the exhibitor and its final customers, as well as the effect that the quality of both these relationships has on the performance obtained by the exhibitor of leisure products and services from the trade show. The variables in our analysis are grouped as shown in Table 1.

Given that, in accordance with the conceptual framework set forth above, pure relationship-marketing components are heavily mixed up with transactional-marketing components, the variables that intervene in the study must firstly be analyzed using measurement scales formed of items from both categories. The statistical analyses that lead to the final model will indicate to which extent the pure relationship-marketing and transactional- 


\section{Tab. 1: Initial analysis variable}

\begin{tabular}{|c|c|c|c|c|c|c|c|}
\hline GROUP & VARIABLE & ITEM & Mean & $\begin{array}{l}\text { Estandar } \\
\text { desviation }\end{array}$ & Skew & Kurtosis & References \\
\hline \multirow{2}{*}{$\begin{array}{l}\text { Complaint } \\
\text { management } \\
\text { (COMPMGMT) }\end{array}$} & $\begin{array}{l}\text { The tourist trade show has a good exhibitor service } \\
\text { system. }\end{array}$ & COMPMGMT1 & 2.79 & 1.121 & .351 & -.530 & \multirow{2}{*}{$\begin{array}{l}\text { Adapted from } \\
\text { [4], [52], [19], } \\
\text { [53]. }\end{array}$} \\
\hline & $\begin{array}{l}\text { The time the tourist trade show organizers take } \\
\text { to solve a problem after we have reported it is } \\
\text { acceptable. }\end{array}$ & COMPMGMT2 & 2.81 & 1.105 & .129 & -.510 & \\
\hline \multirow{7}{*}{$\begin{array}{l}\text { Business- } \\
\text { to-business } \\
\text { relationship } \\
\text { (B2B) }\end{array}$} & $\begin{array}{l}\text { We will continue to attend this tourist trade show even } \\
\text { if the price for each exhibitor increases considerably. }\end{array}$ & B2B1 & 2.23 & 1.095 & .618 & -.350 & \multirow{7}{*}{$\begin{array}{l}\text { Adapted from } \\
\text { [28], [12], [58], } \\
{[17],[36],[42] .}\end{array}$} \\
\hline & $\begin{array}{l}\text { We will recommend that other businesses in the } \\
\text { industry attend this tourist trade show. }\end{array}$ & B2B2 & 2.41 & 1.135 & .436 & -.531 & \\
\hline & $\begin{array}{l}\text { We consider that this tourist trade show is equipped } \\
\text { to address exhibitor's needs and problems } \\
\text { adequately. }\end{array}$ & B2B3 & 2.84 & 1.071 & -.005 & -.383 & \\
\hline & $\begin{array}{l}\text { The trade show organizers are concerned about our } \\
\text { receiving good service. }\end{array}$ & B2B4 & 3.04 & 1.154 & -.241 & -.883 & \\
\hline & $\begin{array}{l}\text { We are confident that the performance we will have } \\
\text { from this tourist trade show will be positive for our } \\
\text { business. }\end{array}$ & B2B5 & 3.58 & 1.126 & -.415 & -.589 & \\
\hline & $\begin{array}{l}\text { The trade show organizers show an interest in our } \\
\text { company's level of satisfaction with the service they } \\
\text { provide. }\end{array}$ & B2B6 & 2.67 & 1.090 & .132 & -.598 & \\
\hline & $\begin{array}{l}\text { Overall, we find the cost-benefit relationship for our } \\
\text { company in this tourist trade show worthwhile. }\end{array}$ & B2B7 & 2.70 & 1.256 & .275 & -.893 & \\
\hline \multirow{9}{*}{$\begin{array}{l}\text { Business-to- } \\
\text {-consumer } \\
\text { relationship } \\
\text { (B2C) }\end{array}$} & $\begin{array}{l}\text { It is essential for us to have a strong long-term } \\
\text { relationship with our customers. }\end{array}$ & $\mathrm{B} 2 \mathrm{C} 1$ & 4.12 & 1.024 & -1.241 & 1.208 & \multirow{9}{*}{$\begin{array}{l}\text { Adapted from } \\
\text { [24], [45], [54], } \\
\text { [38]. }\end{array}$} \\
\hline & $\begin{array}{l}\text { Our customers can participate in designing our } \\
\text { products/services. }\end{array}$ & $\mathrm{B} 2 \mathrm{C} 2$ & 2.47 & 1.340 & .409 & -1.029 & \\
\hline & $\begin{array}{l}\text { Our company defines its goals bearing in mind our } \\
\text { customers' goals. }\end{array}$ & $\mathrm{B} 2 \mathrm{C} 3$ & 3.78 & 1.142 & -.859 & .172 & \\
\hline & $\begin{array}{l}\text { We know what tourist products or services are best } \\
\text { suited for each customer. }\end{array}$ & B2C4 & 3.97 & .885 & -.384 & -.545 & \\
\hline & $\begin{array}{l}\text { We know what our customers expect from our } \\
\text { company. }\end{array}$ & $\mathrm{B} 2 \mathrm{C} 5$ & 4.11 & .918 & -.788 & -.055 & \\
\hline & $\begin{array}{l}\text { We offer tourist services/solutions anticipating our } \\
\text { customers' needs. }\end{array}$ & B2C6 & 3.52 & 1.025 & -.397 & -.218 & \\
\hline & $\begin{array}{l}\text { We use our customers' information to improve our } \\
\text { tourist products/services. }\end{array}$ & $\mathrm{B} 2 \mathrm{C} 7$ & 3.79 & 1.011 & -.676 & .194 & \\
\hline & $\begin{array}{l}\text { Our customers know our company's products and } \\
\text { services. }\end{array}$ & $\mathrm{B} 2 \mathrm{C} 8$ & 3.66 & .956 & -.359 & -.275 & \\
\hline & $\begin{array}{l}\text { We believe our customers are satisfied with their } \\
\text { relationships with our companies' sales team. }\end{array}$ & $\mathrm{B} 2 \mathrm{C} 9$ & 3.97 & .802 & -.397 & -.020 & \\
\hline \multirow{7}{*}{$\begin{array}{l}\text { Performance } \\
\text { (PERF) }\end{array}$} & $\begin{array}{l}\text { We consider the trade show to be a very effective tool } \\
\text { for generating new business. }\end{array}$ & PERF1 & 3.55 & 1.103 & -.234 & -.728 & \multirow{7}{*}{$\begin{array}{l}\text { Adapted from } \\
\text { [2], [31], [47], } \\
{[56],[7]}\end{array}$} \\
\hline & $\begin{array}{l}\text { Among our different efforts aimed at customer loyalty, } \\
\text { the trade show is one of the most effective. }\end{array}$ & PERF2 & 3.01 & 1.200 & .126 & -.770 & \\
\hline & Greater awareness of the companies' activities & PERF3 & 3.56 & 1.199 & -.677 & -.343 & \\
\hline & Enhanced company image & PERF4 & 3.67 & .901 & -.492 & .353 & \\
\hline & Ability to increase sales figures & PERF5 & 2.80 & 1.104 & .288 & -.546 & \\
\hline & Ability to attract new customers & PERF6 & 3.40 & 1.215 & -.289 & -.866 & \\
\hline & Ability to strengthen customer loyalty & PERF7 & 2.44 & 1.122 & .564 & -.302 & \\
\hline
\end{tabular}


marketing components continue to be mixed, or whether some should be discarded.

The operational definition of the complaint management variable is based on the twodimensional model after Stauss [51]. The first dimension has to do with how satisfactory the "attention" obtained during the complaint management procedure is. The second dimension is the "efficiency" observed in handling the complaint in terms of satisfaction with the time that elapses until the problem is solved. The measurement scales of the two dimensions are further explained later. Moreover, there is some controversy regarding the dimensions that comprise relational quality [40]. According to diverse authors [41], [36], [38], this variable is formed of three dimensions: satisfaction, trust, and commitment. Other authors add further dimensions to the ones already mentioned or consider that others are more appropriate [28], [58], [57], [42]. Others again consider that relational quality can be considered a construct of major importance [10], [18], which is the definition adopted here for both Business-to-business (B2B) and Business-to-customer (B2C) relationships, but including in the measurement scale items from the three dimensions mentioned above, i.e. satisfaction, trust, and commitment.

This enables us to posit the following hypotheses:

$\boldsymbol{H}_{\mathbf{1}}$ : The quality of the relationship between the leisure trade show venue and the exhibitors has a positive effect on the relationship quality between the exhibitors and their customers.

$\boldsymbol{H}_{2}$ : The quality of the relationship between the exhibitors and their customers has a positive effect on the performance that the exhibitors get from the trade show.

$\boldsymbol{H}_{3}$ : The quality of the relationship between the leisure trade show venue and the exhibitors has a positive effect on the performance that the exhibitors get from the trade show.

$\boldsymbol{H}_{4}$ : The way in which complaints are managed by the leisure trade show organization has a positive effect on the quality of the relationship between the leisure trade show organization and the exhibitors.

Accordingly with the variables and the previous hypotheses we posit the following model subject to contrasting represented in Figure 1.

\section{Methodology}

\subsection{Sample Data}

The study population includes the 333 businesses that exhibited at the EXPO-OCIO leisure trade show in Madrid in 2009. According to the information provided by the organizing committee, the trade show was attended by over 500,000 visitors - in other words, potential customers for the exhibitors.

The procedure for collecting information was a questionnaire. It has been the method of choice in several research studies about the trade show industry [6], [7], [35], [50], [32].

The field work was carried out in three stages: the first took place during the leisure trade show by handing out a questionnaire to the sales manager for each exhibitor, along

\section{Fig. 1: Model subject to contrasting}

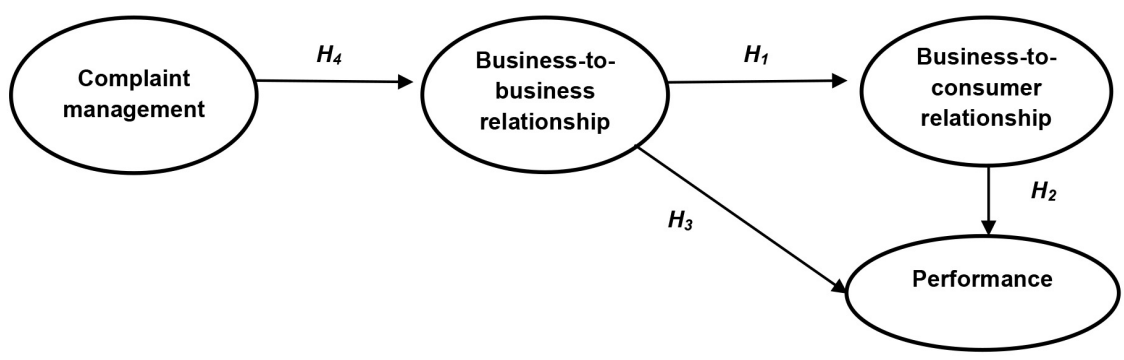


with a prepaid envelope so the survey could be returned by post. The purpose of the survey was explained to each one of the managers. The second stage took place one month after the trade show closed, and involved sending out the questionnaires by post with a letter of introduction and a prepaid envelope. Last of all, the third stage involved two other similar mailings; one two months after the trade show had closed and another one in mid-September, to avoid non-responses over the summer holiday period. Once the field work was completed, a total of 198 questionnaires had been collected, 181 of which were valid, with a $5.03 \%$ sampling error for the least favorable case and a $95.5 \%$ confidence level.

The formula used for calculating the sampling error (SE) with a $95.5 \%$ confidence level was as follows:

$$
\begin{aligned}
& S E=\sqrt{\left[\frac{p q 2^{2}}{n}\right]\left[\frac{N-n}{N-1}\right]}= \\
& =\sqrt{\left[\frac{1}{181}\right]\left[\frac{333-181}{333-1}\right]}=0.050
\end{aligned}
$$

The measurement scales for the variables were drawn from bibliographical reviews about the subject, with certain adaptations to the trade show context [21], [23], [10], [58], [18], [26], [14].

Most of the survey respondents that were businesses exhibiting at EXPO-OCIO were between 10 and 19 years old (almost 30\%), although there were companies of all ages (1 to 4,5 to 9 , and 20 to 49 -year-old businesses were more or less equally represented, with about $20 \%$ from each of these groups). More than half the businesses in the sample $(52 \%)$ had 6 to 50 employees. If we also consider that almost $20 \%$ of the businesses had 5 employees or less, we can safely say that about $70 \%$ of the companies attending EXPO-OCIO were SMEs. It is important to note that almost $30 \%$ of the sample had an annual turnover of 100 million euros or more, although one must also take into account that turnover for $43 \%$ of the businesses was under 7 million euros.

We should describe some of the characteristics of the sample that are specifically related to this study: according to the data we collected, the survey respondents' main goal for bringing their companies to EXPO-OCIO was to make new contacts with potential buyers, as stated by $69.1 \%$ of the surveyed businesses, although they also considered it essential to promote the company's image and improve its reputation (58\%). We should also highlight other important goals for exhibitors, such as receiving orders and generating sales $(49.7 \%)$, providing information about the leisure products and their uses $(48.1 \%)$, having access to customers who would otherwise be difficult to reach $(47.5 \%)$ and introduce new leisure products and/or developments (45.3\%). Clearly, since this is a leisure trade show primarily aimed at final consumers and specialized retailers, sales objectives are more relevant than they would be in other kinds of trade shows, such as industrial shows where exhibitors tend to be more focused on non-sales objectives.

On the other hand, the main reason for businesses in the survey deciding not to attend as exhibitors was the high cost involved in doing so $(59.7 \%)$. This is because most of the businesses in the sample were SMEs and therefore had fewer resources for drawing the public over to their stands than larger companies, and because they were not as well equipped for turning those new contacts into customers. Among the surveyed businesses, $52.5 \%$ mentioned another relevant reason for not attending, namely that the trade show organization did not do its job properly. The least quoted reason for not attending was the company's lack of qualified staff $(2.2 \%)$, a fact that may seem surprising given the importance that some researchers have attributed to this factor [55].

\subsection{Statistical Techniques}

The analysis of the constructs' behavior in the model has been carried on by means of Structural Equations Modeling (SEM), this being a technique that allows the analysis of relationships among constructs that belong to complex theoretical structures [37], [13]. There are two procedures in estimating the SEM parameters. One of them is based on covariance analysis, and it is developed with the aid of LISREL, EQS or AMOS software, for instance. The other procedure is based on variance or component analysis, and it is implemented by means of Partial Least Squares (PLS) technique [20]. The main difference between PLS and other SEM techniques is found in the goals that are respectively addressed. According to 
[29], the approach that is based on covariance analysis is better suited for those situations in which an existent theory is well consolidated and the focus of the research is rather on the model. On the other hand PLS should be applied in those research domains in which the theory is in a previous stage of development, this being the case of the research presented in this article. In addition, the PLS technique allows for the using of small samples [3], it doesn't presuppose either a definite statistical model or a specific measurement scale, and it doesn't $\mathrm{n}$ need data sources with standard or previously known statistical distributions [11]. In the present research the PLS technique was implemented by means of the SmartPLS 2.0 software.

In order to determine whether any hypothesis or item had to be removed before performing the analysis, we analyzed the correlations for each hypothesis (Tab. 2).

In $\boldsymbol{H}_{1}$ the associated correlations show that the business-to-business relationship is not related to a company's concern with maintaining strong long-term relationships with its customers, nor with the customers' role in designing a company's products/services, nor with the customers' awareness of the company's products and services. Therefore, these variables are removed for analyzing this hypothesis.

The analysis of the correlations for $\boldsymbol{H}_{2}$ indicates the need to remove the dimension of the performance variable relating to a greater awareness of the company's activities, given that it is not related to the relationship between exhibitor and consumer.

The variables that were removed in $\boldsymbol{H}_{3}$ show that the relationship between exhibitor and trade show organizers is not related to the company's performance at the trade show as an effective tool to achieve customer loyalty or to attract new consumers.

Once the correlations for $\boldsymbol{H}_{4}$ were analyzed and shown in Table 2, it became apparent that complaint management did not have an effect on either the decision on the part of exhibiting companies to attend the show even facing possible price rises, nor their evaluation regarding whether it was worth attending, considering the cost-benefit ratio obtained.

The variables were analyzed as single constructs. Therefore, bearing in mind the composite reliability index for each case, none of the hypotheses had to be removed.

\section{Tab. 2: Correlations for hypotheses}

\begin{tabular}{|c|c|c|c|c|c|c|c|c|c|c|c|}
\hline \multicolumn{12}{|c|}{ Correlations for $\mathrm{H}_{1}$} \\
\hline \multicolumn{2}{|c|}{ VARIABLE } & B2C1 & B2C2 & B2C3 & B2C4 & B2C5 & B2C6 & $\mathrm{B} 2 \mathrm{C} 7$ & B2C8 & B2C9 & CRI \\
\hline \multirow{2}{*}{ B2B } & CORRELATION & 0.180 & 0.254 & 0.410 & 0.396 & 0.359 & 0.405 & 0.308 & 0.264 & 0.367 & \multirow{2}{*}{0.816} \\
\hline & ALPHA & 0.356 & 0.053 & 0.000 & 0.001 & 0.000 & 0.000 & 0.002 & 0.035 & 0.000 & \\
\hline
\end{tabular}

\begin{tabular}{l|l|c|c|c|c|c|c|c|c}
\hline \multicolumn{10}{c}{ Correlationsfor $\mathrm{H}_{2}$} \\
\hline \multicolumn{2}{l|}{ VARIABLE } & PERF1 & PERF2 & PERF3 & PERF4 & PERF5 & PERF6 & PERF7 & CRI \\
\hline \multirow{2}{*}{ B2C } & CORRELATION & 0.436 & 0.415 & $\mathbf{0 . 2 6 0}$ & 0.368 & 0.350 & 0.498 & 0.374 & \multirow{2}{*}{0.801} \\
\cline { 2 - 28 } & ALPHA & 0.000 & 0.000 & $\mathbf{0 . 0 2 3}$ & 0.002 & 0.001 & 0.000 & 0.000 & \\
\hline
\end{tabular}

\begin{tabular}{l|l|c|c|c|c|c|c|c|c}
\hline \multicolumn{10}{l|}{ Correlationsfor $\mathrm{H}_{3}$} \\
\hline \multicolumn{2}{l|}{ VARIABLE } & PERF1 & PERF2 & PERF3 & PERF4 & PERF5 & PERF6 & PERF7 & CRI \\
\hline \multirow{2}{*}{ B2B } & CORRELATION & 0.380 & $\mathbf{0 . 1 9 0}$ & 0.450 & 0.301 & 0.387 & $\mathbf{0 . 2 0 1}$ & 0.368 & \multirow{2}{*}{0.873} \\
\cline { 2 - 25 } & ALPHA & 0.000 & $\mathbf{0 . 0 6 7}$ & 0.000 & 0.004 & 0.001 & $\mathbf{0 . 0 5 4}$ & 0.000 & \\
\hline
\end{tabular}

\begin{tabular}{l|l|c|c|c|c|c|c|c|c}
\hline \multicolumn{10}{c|}{ Correlationsfor $\mathrm{H}_{4}$} \\
\hline \multicolumn{1}{l|}{ VARIABLE } & B2B1 & B2B2 & B2B3 & B2B4 & B2B5 & B2B6 & B2B7 & CRI \\
\hline \multirow{2}{*}{ COMPMGMT } & CORRELATION & $\mathbf{0 . 2 5 0}$ & 0.380 & 0.427 & 0.416 & 0.596 & 0.401 & $\mathbf{0 . 2 9 8}$ & \multirow{2}{*}{0.866} \\
\cline { 2 - 28 } & ALPHA & $\mathbf{0 . 0 7 8}$ & 0.000 & 0.000 & 0.001 & 0.000 & 0.002 & $\mathbf{0 . 0 6 0}$ & \\
\hline
\end{tabular}


Evaluation of the measurement model

\begin{tabular}{|c|c|c|c|c|}
\hline \multicolumn{5}{|c|}{ Initial analysis variables } \\
\hline CONSTRUCT & \multicolumn{2}{|c|}{ ITEM } & \multicolumn{2}{|c|}{ LOADING $(\lambda)$} \\
\hline \multirow{2}{*}{ Complaint management } & \multicolumn{2}{|c|}{ COMPMGMT1 } & \multicolumn{2}{|c|}{0.9418} \\
\hline & \multicolumn{2}{|c|}{ COMPMGMT2 } & \multicolumn{2}{|c|}{0.9018} \\
\hline \multirow{5}{*}{$\begin{array}{l}\text { Business-to-business } \\
\text { relationship }\end{array}$} & \multicolumn{2}{|c|}{ B2B2 } & \multicolumn{2}{|c|}{0.7857} \\
\hline & \multicolumn{2}{|c|}{ B2B3 } & \multicolumn{2}{|c|}{0.8166} \\
\hline & \multicolumn{2}{|c|}{ B2B4 } & \multicolumn{2}{|c|}{0.8116} \\
\hline & \multicolumn{2}{|c|}{ B2B5 } & \multicolumn{2}{|c|}{0.7889} \\
\hline & \multicolumn{2}{|c|}{ B2B6 } & \multicolumn{2}{|c|}{0.7314} \\
\hline \multirow{6}{*}{$\begin{array}{l}\text { Business-to-customer } \\
\text { relationship }\end{array}$} & \multicolumn{2}{|c|}{ B2C3 } & \multicolumn{2}{|c|}{0.6906} \\
\hline & \multicolumn{2}{|c|}{ B2C4 } & \multicolumn{2}{|c|}{0.7626} \\
\hline & \multicolumn{2}{|c|}{ B2C5 } & \multicolumn{2}{|c|}{0.7869} \\
\hline & \multicolumn{2}{|c|}{ B2C6 } & \multicolumn{2}{|c|}{0.6465} \\
\hline & \multicolumn{2}{|c|}{ B2C7 } & \multicolumn{2}{|c|}{0.6401} \\
\hline & \multicolumn{2}{|c|}{ B2C9 } & \multicolumn{2}{|c|}{0.6551} \\
\hline & PERF & & & \\
\hline Dorformanas & PER & & & \\
\hline 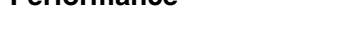 & PERF & & & \\
\hline & PERF & & & \\
\hline & ite Reliability Ir & x (CRI) & & \\
\hline$C P I$ & COMPMGMT & B2B & B2C & PERF \\
\hline CnI & 0.9190 & 0.8907 & 0.8509 & 0.7836 \\
\hline Conver & d discriminant & dity anal & & \\
\hline AVE & 0.850 & 0.620 & 0.489 & 0.4801 \\
\hline & COMPMGMT & B2B & B2C & PERF \\
\hline COMPMGMT & 0.922 & - & - & - \\
\hline B2B & 0.566 & 0.787 & - & - \\
\hline B2C & 0.098 & 0.259 & 0.699 & - \\
\hline PERF & 0.085 & 0.562 & 0.333 & 0.693 \\
\hline
\end{tabular}

Two stages appear in the PLS analysis [3]: the first involves examining the validity and reliability of the measurement tool and the second is an evaluation of the structural model.

Evaluation of the measurement model: The individual reliability of each item, the reliability of the construct, its convergent validity, and its discriminant validity must be analyzed (see Tab. 3).
By analyzing the reliability of the items we analyze the loadings $(\lambda)$ for each indicator in relation to its latent variable. For an indicator to be accepted as part of a construct its loading must be equal to or greater than 0.707 . The following items were removed because they were lower than 0.707: B2C3, B2C6, B2C7, B2C9, PERF4, PERF7. 


\section{Marketing \& obchod}

The reliability of a construct is used to check the internal consistency of all the indicators by measuring the concept; in other words, it determines how consistently the specified variables measure the same latent variable. It can be measured with the composite reliability index. It is generally accepted that a minimum value of 0.7 suffices for early stages of research. The latent constructs are reliable because they all show measures of internal consistency above 0.7 .

Convergent validity was established by analyzing the Average Variance Extracted $(A V E)$, having acknowledged that the AVE values must be higher than 0.5 , which means that over $50 \%$ of the construct's variance is due to its indicator. In the case of this paper, the average variances extracted from the B2C and PERF constructs were below the minimum value, and therefore the convergent validity of the related constructs in the structural model could not be accepted.

The degree to which a construct differs from the other constructs in a model is determined by the discriminant validity test. To establish discriminant validity, the AVE value must be higher than the variance shared by the construct and the other represented constructs. To simplify the comparison, each element along the main diagonal (square root of AVE) must be higher than the remaining elements in its row and the corresponding column-correlations

\section{Tab. 4: Evaluation of the measurement modified model}

\begin{tabular}{|c|c|c|c|c|}
\hline \multicolumn{5}{|c|}{ Variables in the modified model } \\
\hline CONSTRUCT & \multicolumn{2}{|c|}{ ITEM } & \multicolumn{2}{|c|}{ LOADING $(\lambda)$} \\
\hline \multirow{2}{*}{ Complaint management } & \multicolumn{2}{|c|}{ COMPMGMT1 } & \multicolumn{2}{|c|}{0.9419} \\
\hline & \multicolumn{2}{|c|}{ COMPMGMT2 } & \multicolumn{2}{|c|}{0.9017} \\
\hline \multirow{5}{*}{$\begin{array}{l}\text { Business-to-business } \\
\text { relationship }\end{array}$} & \multicolumn{2}{|c|}{ B2B2 } & \multicolumn{2}{|c|}{0.7847} \\
\hline & \multicolumn{2}{|c|}{ B2B3 } & \multicolumn{2}{|c|}{0.8173} \\
\hline & \multicolumn{2}{|c|}{ B2B4 } & \multicolumn{2}{|c|}{0.8086} \\
\hline & \multicolumn{2}{|c|}{ B2B5 } & \multicolumn{2}{|c|}{0.7901} \\
\hline & \multicolumn{2}{|c|}{ B2B6 } & \multicolumn{2}{|c|}{0.7341} \\
\hline \multirow{2}{*}{$\begin{array}{l}\text { Business-to-customer } \\
\text { relationship }\end{array}$} & \multicolumn{2}{|c|}{$\mathrm{B} 2 \mathrm{C} 4$} & \multicolumn{2}{|c|}{0.8466} \\
\hline & \multicolumn{2}{|c|}{$\mathrm{B} 2 \mathrm{C} 5$} & \multicolumn{2}{|c|}{0.8861} \\
\hline \multirow{2}{*}{ Performance } & \multicolumn{2}{|c|}{ PERF1 } & \multicolumn{2}{|c|}{0.8889} \\
\hline & \multicolumn{2}{|c|}{ PERF5 } & \multicolumn{2}{|c|}{0.7958} \\
\hline \multicolumn{5}{|c|}{ CRI for the modified model } \\
\hline \multirow{2}{*}{ CRI } & COMPMGMT & B2B & B2C & PERF \\
\hline & 0.9190 & 0.8907 & 0.8620 & 0.8312 \\
\hline \multicolumn{5}{|c|}{ Convergent and discriminant validity analysis } \\
\hline \multirow[t]{2}{*}{ AVE } & 0.850 & 0.620 & 0.758 & 0.712 \\
\hline & COMPMGMT & B2B & B2C & PERF \\
\hline COMPMGMT & 0.922 & - & - & - \\
\hline B2B & 0.564 & 0.787 & - & - \\
\hline B2C & 0.147 & 0.293 & 0.870 & - \\
\hline PERF & 0.076 & 0.571 & 0.264 & 0.844 \\
\hline
\end{tabular}


between constructs [3]. In the posited model, the constructs met the specified condition. Therefore, discriminant validity could be accepted (Table 3).

In summary, when we evaluated the measurement model, we removed the $\mathrm{B} 2 \mathrm{C} 3$, $\mathrm{B} 2 \mathrm{C} 7, \mathrm{~B} 2 \mathrm{C} 6$, and $\mathrm{B} 2 \mathrm{C} 9$ indicators from the construct for the business-to-customer relationship (loading $<0.70$ ); the PERF4 and PERF7 indicators were removed from the resulting construct (loading < 0.70 ); there were no reliability problems; in terms of convergent validity, the AVE was insufficient for the $\mathrm{B} 2 \mathrm{C}$ and PERF constructs (AVE < 0.50), and therefore we had to wait and see what happened when we reestimated the model after removing the items; there were no discriminant validity problems.

Initially, we made no decision about evaluating the structural model until we had evaluated the model resulting after the measurement model had been modified. Therefore, we modified the measurement model by removing the indicators with the lowest loading and then repeated the estimation, as shown in Table 4.

Once the items were reliable, we could safely state that all the indicators were accepted as parts of their respective constructs. The latent constructs were reliable because they all showed a Composite Reliability Index above 0.7 .Convergent validity of the constructs included in the structural model was accepted, because in the AVE analysis it was well above the minimum value of 0.5 for all cases. In addition, the model had discriminant validity because the AVE value was higher than the variance that was shared by the construct and the other represented constructs.

Evaluation of the structural model: Once the validity and reliability of the measurement tool had been proven, we had to determine whether the structural model supported the proposed research model; in order to do so, we had to consider the standardized path coefficients $(\beta)$ and the explained variance for the endogenous variables $\left(R^{2}\right)$.

The path coefficients or standardized regression weights $(\beta)$ provide information as to the extent to which the predictive variables contribute to the explained variance of the endogenous variables. The desirable values for each path or relationship ought to be above 0.3 , where the lower limit is considered to be 0.2 . This condition has to be met together with the significance level (significance levels $\mathrm{n}$ : $\left.p<0.05 t_{(0.05 ; 499)}=1.64791345\right)$. To check the significance of the $\beta$ coefficients we used the non-parametric bootstrap method, used to estimate the stability of the PLS estimates; thus, a resampling procedure was used to generate 500 sub-samples and obtain $t$ statistics. All the factor loadings turned out to be significant, with a $p<0.05$ significance level. These levels indicate the significance of the structural paths, determining whether the posited hypotheses are accepted or rejected.

As far as these requirements were concerned, all the hypotheses were accepted except for the one $\left(\boldsymbol{H}_{2}\right)$ that related the businessto-customer relationship quality to achieved business performance, which gave a $\beta$ value of 0.1064 (2.7495). The rest of the $\beta$ values were as following: $\beta=0.2932$ (7.0787) for $\boldsymbol{H}_{1} ; \beta=0.5394$ (17.2118) for $\boldsymbol{H}_{3} ; \beta=0.5637$ (17.8683) for $\boldsymbol{H}_{4}$. The resulting model can be seen in Figure 2.

The explained variance of the endogenous variables $\left(R^{2}\right)$ indicates the amount of variance in the construct that is explained by the model: $R^{2}$ must be greater than or equal to 0.1 . In this study, two of the three latent variables had an acceptable explained variance: the businessto-business relationship was explained in $32 \%$ and performance in $34 \%$. However, the predictive power of the business-to-customer relationship variable was only $9 \%$, below the minimum required value.

Finally, the predictive relevance of the dependent variables in the model were obtained using the Stone-Geissner Q-Square test calculated with a blindfolding procedure. This procedure consists of omitting certain data when one estimates a latent variable based on other independent variables; one then attempts to estimate the data using the previously estimated parameters. The process is repeated until each data item has been omitted and estimated. $A Q^{2}$ value higher than 0 means that the model has predictive relevance. The test gives a positive value for all the latent variables, which makes it possible to confirm the model's adequate predictive quality.

\section{Conclusions}

Adopting a good complaint management system appears to have an effect on the development of a relationship strategy between general trade show organizers and exhibitors [21]. This first objective was addressed in the 


\section{Fig. 2: Resulting model}

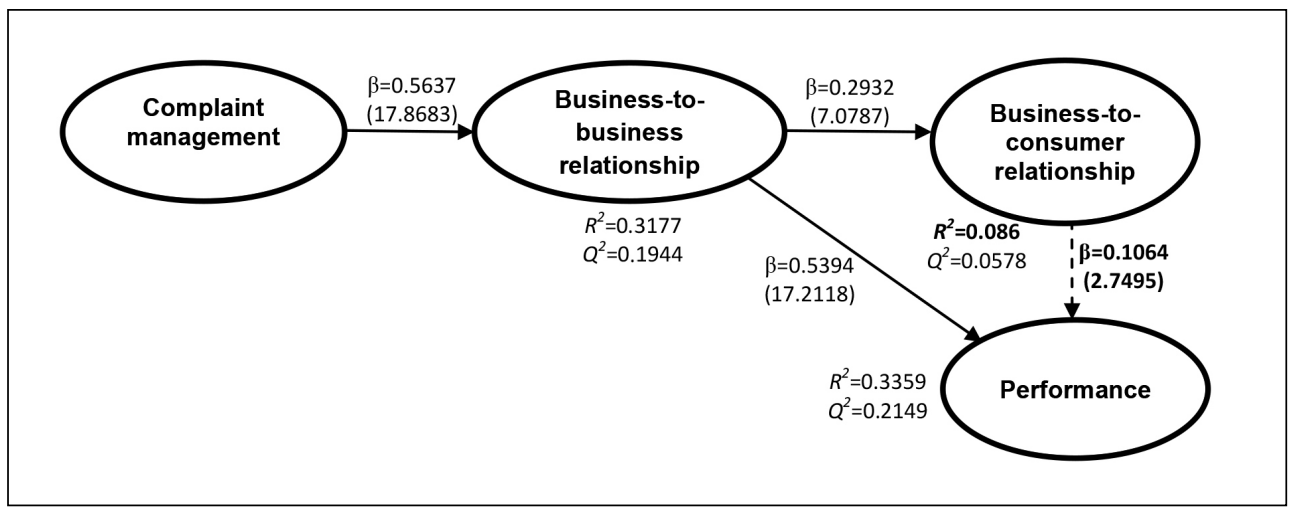

Source: own

specific case of leisure products and services by examining the opportunity that leisure trade shows offer businesses for establishing individual relationships with their customers, listening to their specific needs and managing their relationships with their customers from a relationship approach [9]. Therefore, leisure trade shows could be viewed as an arena where relationship quality is the key, since that is where customer complaint management takes place alongside relationship marketing between organizations. This postulate was confirmed in our case.

We also analyzed the effect that the quality of the relationship between the leisure trade fair venue and the exhibitors had on the quality of the relationship between the exhibitors and their customers. The posited model we analyzed enabled us to confirm that the quality of the relationship between the leisure trade show venue and the exhibitor influences the way in which the exhibitor develops its relationship with its customers. In other words, in addition to the positive effect noted by several authors [15], [28], in the case of leisure trade shows the quality of the relationship between organizations affects the way in which exhibitors approach their relationships with their customers -as it had been suggested earlier [22] for other types of trade events-, even if the quality of the business-to-customer relationship does not have a direct influence on the exhibitor's business performance at the leisure trade show.
Our observations about the interrelations between the quality of the relationships that the different actors have with one another and the final performance achieved by exhibitors at the leisure trade show deserve an additional comment given its implications for marketing management theory and practice in the specific field that is considered here. The quality of the relationship between the trade show venue and the exhibitor has a relevant impact on the performance the exhibitor achieves at the trade show, probably due to its enabling optimal development of prior efforts and planning whose general relevance has already been suggested in the marketing literature [55], [34].

On the other hand, the relatively low impact of business-to-customer relationship quality on final business performance at the trade show is probably due to the fact that exhibitors of leisure products and services foster this relationship quality in all their marketing activities throughout the business year, among which the leisure trade show presence is just one specific effort in a limited time frame. No other result could have come from this relationship because the trade show has a limited role within the overall efforts considered by the development of a company's business-to-customer relationship. In fact, the predictive power of performance by businessto-customer relationship quality does not reach the minimum required level.

These results may be due to the fact that all the variables used to measure relationship quality among organizations refer to efforts 
carried out during the leisure trade show, whereas the efforts that contribute to businessto-consumer relationship quality are carried out throughout the entire year. Ultimately, the variables that contribute to the quality of the exhibitor-customer relationship are not specifically determined at the trade show, but rather are a part of the company's ongoing marketing activities. Therefore, the quality of the relationship between the leisure trade show venue and the exhibitor appears to act as a catalyst for the latter to act upon the quality of its relationship with the final customer of leisure products and services, not only during the trade show. However, the greater the exhibitor's satisfaction, the better the specific performance at the trade show. This positive effect of the quality of the relationship between organizations on the exhibitor's business performance adds to the benefits which, as marketing tools that facilitate direct contact between both parties, had also been pointed out in the case of other sector's trade shows [8].Complaint management strategies at the show have thus a rather cumulative effect that strongly contributes to the overall return of the exhibitor's marketing investments.

Summarizing the implications of the research, it should be noted that appropriate management of exhibitors' complaints by the leisure trade show organizers has a positive effect on the relationship between both parties; therefore, in terms of the trade show's image and prestige, the organizers must devote time and effort to handling exhibitors' complaints appropriately and effectively. This amounts to no more than applying the common knowledge in the field of relationship marketing among organizations, and consequently it should be an integral part of the marketing strategies that are carried over by the trade show organizer. But the leisure trade show organizers must also pursue an adequate relationship quality with exhibiting businesses, because this will in turn influence the exhibitors' relationship with their customers and, therefore, the greater or lesser effectiveness (performance) of the trade show as a marketing tool for companies that try to promote leisure products and services. This later one is an unexpected result in our research since is far from obvious than relationship marketing strategies pertaining to the organizational domain could have a role on the relationship marketing effectiveness that belong exclusively to the interrelations of a firm with its end customers. All these observed facts and consequences seem to call for an integrated view of both relationship and transactional marketing on the one hand, and an integrated view of the strategies of all the parties involved (in our case the show organizer and the exhibitor) on the other-an integrated view that is relevant for both the theoretical and the practitioner marketing field.

Finally, we would like to point out that our study focused on the results obtained during one specific year. It may be interesting to perform the same research over the course of several periods to be able to follow the development of the different variables we examined longitudinally. It would also be interesting to carry this research over to the area of international leisure events, and thus be able to compare the behavior of the different leisure trade shows.

\section{References}

[1] ASOCIACIÓN DE FERIAS ESPAÑOLAS. Estadísticas 2006, 2007 [online]. AFE, c2010 [cit. 2010-09-15]. Available from: http://www. afe.es/dame_dato_n_prensa,96,1,1.htm.

[2] BANTING, P.M., BLENKHORN, D.L. The role of industrial trade shows. Industrial Marketing Management. 1974, Vol. 3, Iss. 5, pp. 285-295. ISSN 0019-8501. DOI: 10.1016/00198501(74)90004-2.

[3] BARCLAY, D., HIGGINS, C., THOMPSON, R. The Partial Least Squares (PLS) approach to causal modelling: personal computer adoption and use as an illustration. Technology Studies: Special Issue on Research Methodology. 1995, Vol. 2, Iss. 2, pp. 285-309. ISSN 0940-9467.

[4] BEJOU, D., PALMER, A. Service failure and loyalty: an exploratory empirical study of airline customers. The Journal of Services Marketing. 1998, Vol. 12, Iss. 1, pp. 7-22. ISSN 0887-6045. DOI: $10.1108 / 08876049810202339$

[5] BERNÉ, C., GARCÍA-UCEDA, M.E. Criteria involved in evaluation of trade shows to visit. Industrial Marketing Management. 2008, Vol. 37, Iss. 5, pp. 565-579. ISSN 0019-8501. DOI: 10.1016/j.indmarman.2006.12.005.

[6] BLYTHE, J. Exhibitor commitment and the evaluation of exhibition activities. International Journal of Advertising. 1999, Vol. 18, Iss. 1, pp. 73-88. ISSN 0265-0487. DOI: 10.1080/02650487.1999.11104745. 
[7] BLYTHE, J. Using trade fairs in key account management. Industrial Marketing Management. 2002, Vol. 31, Iss. 7, pp. 627635. ISSN 0019-8501. DOI: 10.1016/S00198501(02)00183-9.

[8] CENTER FOR EXHIBITION INDUSTRY RESEARCH. Role and value of face-to-face marketing study [online]. CEIR, 2003 [cit. 201112-20]. Available from: http://www.ceir.org/ content/docs/Index\%20of\%20Products.pdf.

[9] CHATTOPADHYAY, S.P. Relationship marketing in an enterprise resource planning environment. Marketing Intelligence and Planning. 2001, Vol. 19, Iss. 2, pp. 136-141. ISSN 0263-4503. DOI: 10.1108/02634500110385444. [10] DE WULF, K., ODEKERKEN-SCHRÖDER, G., IACOBUCCI, D. Investments in consumer relationships: a cross-country and crossindustry exploration. Journal of Marketing. 2001, Vol. 65, Iss. 4, pp. 33-50. ISSN 00222429. DOI: $10.1509 / \mathrm{jmkg} \cdot 65.4 .33 .18386$.

[11] FALK, R.F., MILLER, N.B. A Primer for soft modelling. Akron, Ohio: The University of Akron, 1992. ISBN 0-9622628-4-6.

[12] FARRELLY, F., QUESTER, P. The effects of market orientation on trust and commitment. The case of the sponsorship business-to-business relationships. European Journal of Marketing. 2003, Vol. 37, Iss. 3/4, pp. 530-553. ISSN 17587123. DOI: 10.1108/03090560310459078.

[13] FORNELL, C., LARCKER, D.F. Evaluating structural models with unobservable variables and measurement error. Journal of Marketing Research. 1981, Vol. 18, Iss. 1, pp.39-50. ISSN 0022-2437. DOI: $10.2307 / 3151312$.

[14] FYNES, B., DE BÚRCA, S., MANGAN, $\mathrm{J}$. The effects of relationship characteristics on relationship quality and performance. International Journal of Production Economics. 2008, Vol. 111, Iss. 1 , pp. 56-69. ISSN 09255273. DOI: 10.1016/j.ijpe.2006.11.019.

[15] GILLILAND, D.I., BELLO, D.C. Two sides to attitudinal commitment: the effect of calculative and loyalty commitment on enforcement mechanism in distribution channels. Journal of the Academy of Marketing Science. 2002, Vol. 30 , Iss. 1 , pp. 24-43. ISSN 0092-0703. DOI: 10.1177/03079450094306.

[16] GOPALAKRISHNA, S., ROSTER, C.A., SRIDHAR, S. An exploratory study of attendee activities at a business trade show. International Journal of Industrial Marketing. 2010, Vol. 25, Iss. 4, pp. 241-248. ISSN 2162-3066. DOI: $10.1108 / 08858621011038199$.
[17] GOURANIS, S.P. Trust and commitment influences on customer retention: insights from business-to-services. Journal of Business Research. 2005, Vol. 58, Iss. 2, pp. 126140. ISSN 0148-2963. DOI: 10.1016/S01482963(03)00122-X.

[18] GRÉGOIRE, Y., FISHER, R.J. The effects of relationship quality on customer retaliation. Marketing Letters. 2006, Vol. 17, Iss. 1, pp. 31-46. ISSN 0923-0645. DOI: 10.1007/s11002006-3796-4.

[19] GRUBER, T., SZMIGIN, I., VOSS, R. The desired qualities of customer contact employees in complaint handling encounters. Journal of Marketing Management. 2006, Vol. 22, Iss. 5-6, pp. 619-642. ISSN 0267-257X. DOI: $10.1362 / 026725706777978721$.

[20] HAENLEIN, M., KAPLAN, A.M. A beginner's guide to partial least squares analysis. Understanding Statistics. 2004, Vol. 3, Iss. 4, pp. 283-297. ISSN 1534-844X. DOI: 10.1207/s15328031us0304_4.

[21] HENNIG-THURAU, $\bar{T} . \quad A$ relationship marketing perspective of complaint satisfaction in service settings: some empirical findings. In: American Marketing Association, Conference Proceedings. American Marketing Association, 2001. pp. 206-213.

[22] HENNIG-THURAU, T., GWINNER, K.P., GREMLER, D. The rationales of services relationships: integrating company-oriented and customer-oriented relational benefits. American Marketing Association, Conference Proceedings. American Marketing Association, 2000. pp. 201-202.

[23] HENNIG-THURAU, T., GWINNER, K.P., GREMLER, D.D. Understanding relationship marketing outcomes. Journal of Services Research. 2002, Vol. 4, Iss. 3 , pp. 230-247. ISSN 1094-6705. DOI: 10.1177/1094670502004003006.

[24] HENNING-THURAU, T., KLEE, A. The impact of customer satisfaction and relationship quality on customer retention: a critical reassessment and model development. Psychology and Marketing. 1997, Vol. 14, Iss. 8, pp. 737-764. ISSN 1520-6793. DOI: 10.1002/ (SICI)1520-6793(199712)14:8<737::AIDMAR2>3.0.CO;2-F.

[25] HOMMEROVA, D. Research concerning the experience of implementation of CRM in companies. E+M Ekonomie a Management. 2009, Vol. 12, Iss. 1, pp.108-122. ISSN 12123609. 
[26] HUNTLEY, J.K. Conceptualization and measurement of relationship quality: Linking relationship quality to actual sales and recommendation intention. Industrial Marketing Management. 2006, Vol. 35, Iss. 6, pp. 703-714. ISSN 0019-8501. DOI: 10.1016/j. indmarman.2005.05.011.

[27] IACOBUCCI, D., HIBBARD, J.D. Toward an encompassing theory of business marketing relationships and interpersonal commercial relationships: an empirical generalization. Journal of Interactive Marketing. 1999, Vol. 13, Iss. 3, pp. 13-33. ISSN 1520-6653. DOI: 10.1002/ (SICI)1520-6653(199922)13:3<13::AIDDIR2>3.0.CO;2-Z.

[28] JONNSON, P., ZINELDIN, M. Achieving high satisfaction in supplierdealer working relationships. Supply Chain Management Journal. 2003, Vol. 8, Iss. $3 / 4$, pp. 224-240. ISSN 2069-5519. DOI: $10.1108 / 13598540310484627$.

[29] JÖRESKOG, K.G., WOLD, H. Systems under Indirect Observation-Causality Structure Prediction. Amsterdam: North Holland Publishing Company, 1982. ISBN 0444-86301-X. [30] KAW, A.-K., LOH, E.W.-Y. The effects of service recovery on consumer satisfaction: a comparison between complainants and noncomplainants. Journal of Services Marketing. 2006, Vol. 20, Iss. 2, pp. 101-111. ISSN 08876045. DOI: $10.1108 / 08876040610657039$.

[31] KERIN, R.A., CRON, W.L. Assesing trade show functions and performance: an exploratory study. Journal of Marketing. 1987, Vol. 51, Iss. 3, pp. 87-94. ISSN 0022-2429. DOI: $10.2307 / 1251649$.

[32] KIRCHGEORG, M., JUNG, K., KLANTE, O. The future of TSw: insights from a scenario analysis. Journal of Business and Industrial Marketing. 2010, Vol. 25, Iss. 4, pp. 301-312. ISSN 0885-8624. DOI: 10.1108/08858621011038261.

[33] KURTULUS, K., NASIR, S. Integration of Comparison Level Theory to Analyze the Relationship between Complaint Recovery Satisfaction and Post-Complaint Consumer Responses. The Business Review. 2008, Vol. 10, Iss. 1, pp. 344-348. ISSN 1553-5827.

[34] LEE, C.H., KIM, S.Y. Differential effects of determinants on multi-dimensions of trade show performance: by three stages of preshow, at-show, and post-show activities. Industrial Marketing Management. 2008, Vol. 37, Iss. 7, pp. 784-796. ISSN 0019-8501.
DOI: 10.1016/j.indmarman.2008.01.006.

[35] LING-ZHONG, L. A perceptual measure of trade shows using fuzzy quality deployment development. Expert Systems with Applications. 2010, Vol. 37, Iss. 5, pp. 3921-3933. ISSN 0957-4174. DOI: 10.1016/j.eswa.2009.11.025. [36] LLORENS, J., FANDOS, J.C., MOLINER, M.A., SÁNCHEZ, J. La calidad de relación en mercados industriales: estados de la cuestión. Innovar. 2006, Vol. 16, Iss. 28, pp. 199-222. ISSN 0121-5051.

[37] MACKENZIE, S.B. Opportunities for improving consumer research through latent variable structural equation modeling. Journal of Consumer Research. 2001, Vol. 28, Iss. 1, pp. 159-166. ISSN 0093-5301. DOI: $10.1086 / 321954$.

[38] MOLINER, M.A., SÁNCHEZ, J., RODRÍGUEZ, R.M., CALLARISA, L.J. Travel Agency Relationship Quality. Annals of Tourism Research. 2007, Vol. 34, Iss. 2, pp. 537-540. ISSN 0160-7383. DOI: 10.1016/j. annals.2006.11.001.

[39] NADIRI, H., TÜMER, M. Retail service quality and behavioral intentions: an empirical application of the retail service quality scale in Northern Cyprus. E+M Ekonomie a Management. 2009, Vol. 12, Iss. 2, pp. 127139. ISSN 1212-3609.

[40] NAUDÉ, P., BUTTLE, F. Assessing Relationship Quality. Industrial Marketing Management. 2000, Vol. 29, Iss. 4, pp. 351361. ISSN 0019-8501. DOI: 10.1016/S00198501(00)00112-7.

[41] ODEKERKEN-SCHRÖDER, G.J., DE WULF, K., SCHUMACHER, P. Strengthening outcomes of retailer-consumer relationships: The dual impact of relationship marketing tactics and consumer personality. Journal of Business Research. 2003, Vol. 56, Iss. 3, pp. 177-190. ISSN 0148-2963. DOI: 10.1016/ S0148-2963(01)00219-3.

[42] RAUYRUEN, P., MILLER, K.E. Relationship quality as a predictor of $\mathrm{B} 2 \mathrm{~B}$ customer loyalty. Journal of Business Research. 2007, Vol. 60, Iss. 1, pp. 21-31. ISSN 01482963. DOI: 10.1016/j.jbusres.2005.11.006.

[43] RINALDO, D., BORGHINI, S., GOLFETTO, F. Exploring visitor experiences at Trade Shows. Journal of Business and Industrial Marketing. 2010, Vol. 25, Iss. 4, pp. 249-258. ISSN 08858624. DOI: $10.1108 / 08858621011038207$.

[44] RITTICHAINUWAT, B., MAIR, J. Visitor attendance motivations at consumer travel 
exhibitions. Tourism Management. 2012, Vol. 33, Iss. 5, pp. 1236-1244. ISSN 0261-5177. DOI: 10.1016/j.tourman.2011.11.002.

[45] SAN MARTíN, S. El compromiso organizacional. Dimensiones y antecedentes. XVII Encuentro de Profesores Universitarios de Marketing, 2005. Madrid, Spain.

[46] SCHOEFER, K., ENNEW, C. The impact of perceived justice on consumers' emotional responses to service complaint experiences. The Journal of Services Marketing. 2005, Vol. 19, Iss. 5, pp. 261-270. ISSN 0887-6045. DOI: 10.1108/08876040510609880.

[47] SHIPLEY, D., EGAN, C., WONG, K.S. Dimensions of trade show exhibiting management. JournalofMarketingManagement. 1993, Vol. 9, Iss. 1, pp. 55-63. ISSN 0267-257X. DOI: 10.1080/0267257X.1993.9964217.

[48] SIMOVÁ, J. Conceptual models of customer value: implications for clothing retailing. E+M Ekonomie a Management. 2009, Vol. 12, Iss. 1, pp. 88-97. ISSN 1212-3609.

[49] SINGH, J., SIRDESHMUKH, D. Agency and trust mechanisms in consumer satisfaction and loyalty judgements. Journal of the Academy of Marketing Sciences. 2000, Vol. 28, Iss. 1, pp.150-167. ISSN 0092-0703. DOI: $10.1177 / 0092070300281014$.

[50] SKALLERUD, K. Structure, strategy and performance of exhibitors at individual booths versus joint booths. Journal of Business and Industrial Marketing. 2010, Vol. 25, Iss. 4, pp. 259-267. ISSN 0885-8624. DOI: 10.1108/08858621011038216.

[51] STAUSS, B. Complaint Satisfaction and Customer Retention. In: 8th AMA Frontiers in Services Conference. Vanderbilt University, Nashville, 1999.

[52] STAUSS, B. The dimensions of complaint satisfaction: process and outcome complaint satisfaction versus cold fact and warm act complaint satisfaction. Managing Service Quality. 2002, Vol. 12, Iss. 3, pp. 173-183. ISSN 0960-4529. DOI:10.1108/09604520210429240. [53] SU, C.T., LIN, C.S. A case study on the application of Fuzzy QFD in TRIZ for service quality improvement. Quality and Quantity. 2008, Vol. 42, Iss. 5, pp. 563-578. ISSN 00335177. DOI: $10.1007 / \mathrm{s} 11135-006-9058-y$.
[54] SUÁREZ, L., VÁZQUEZ, R., DÍAZ, A. $M$. Antecedentes y consecuencias del capital relacional: una aplicación a las agencias de viajes minoristas. Revista Española de Investigación de Marketing ESIC. 2005, Vol. 9, Iss. 2, pp. 77-110. ISSN 1138-1442.

[55] TANNER, JR., J.F. Leveling the playing field: factors influencing trade show success for small companies. Industrial Marketing Management. 2002, Vol. 31, Iss. 3, pp. 229239. ISSN 0019-8501. DOI: 10.1016/S00198501(00)00132-2.

[56] TANNER, JR., J.F., CHONKO, L.B. Trade Show objectives, management and staffing practices. Industrial Marketing Management. 1995, Vol. 24, Iss. 4, pp. 257-264. ISSN 00198501. DOI: 10.1016/0019-8501(94)00082-8.

[57] WONG, Y.H., HUNG, H., CHOW, W-K. Mediating effects of relationship quality on customer relationships: an empirical study in Hong Kong. Marketing Intelligence and Planning . 2007, Vol. 25, Iss. 6 , pp. 581-596. ISSN 02634503. DOI: $10.1108 / 02634500710819950$.

[58] WOO, K.-S., ENNEW, C.T. Measuring business-to-business professional service quality and its consequences. Journal of Business Research. 2005, Vol. 58, pp. 11781185. ISSN 0148-2963. DOI: 10.1016/j. jbusres.2004.05.003.

\section{Ainhoa Rodríguez, Ph.D. Universidad Nacional de Educación a Distancia Department of Business Administration arodriguez@cee.uned.es}

María Dolores Reina, Ph.D. Universidad Nacional de Educación a Distancia Department of Business Administration mreina@cee.uned.es

Ramón Rufín, Ph.D. Universidad Nacional de Educación a Distancia Department of Business Administration rrufin@cee.uned.es 


\title{
Abstract
}

\section{RELATIONSHIP QUALITY AND EXHIBITOR'S PERFORMANCE IN LEISURE TRADE SHOWS}

\author{
Ainhoa Rodríguez, María Dolores Reina, Ramón Rufín
}

This paper analyzes the roll of complaint management as a factor that may influence the quality of the relationship between the participants at leisure trade shows, the quality of these relationships being a relevant factor on business performance.

Therefore, we study the quality of relationship between the leisure trade show organizer and the exhibitor as well as between the latter and their end customers in order to determine whether influences exist between both relationships, and the effect that the relationship quality could have on the performance the exhibitor achieves at the trade show. This established four initial hypotheses and analysis was performed through the development of a Structural Equations Model (SEM). We applied the Partial Least Squares (PLS) method to establish the relationships between the constructs as well as the predictive power of the structural model.

The posited model we analyzed enabled us to confirm the existence of a positive effect between the two relationships studied (relationship between leisure trade fair venue and exhibitor; and relationship between exhibitor and customer). This means that the quality of the relationship between the leisure trade fair venue and the exhibitors influences both the way in which exhibitors approach and develop their relationships with their customers. In addition, our results show the existence of a relevant impact of the relationship quality between organizations on the performance obtained by the exhibitor of leisure products and services at the end of the show. This in turn is an indication of the important role of complaint management as a key tool for achieving a good business performance and ensuring the future of trade shows.

Key Words: Leisure shows, complaint management, relationship quality, leisure products and services.

JEL Classification: M31, M10.

DOI: 10.15240/tul/001/2015-3-012 